\title{
In search for hidden repertoire gems: A performer's approach to Russian and Soviet clarinet music
}

\author{
Lectio praecursoria
}

\begin{abstract}
The public examination of Anne Elisabeth Piirainen on 22 February 2021 at Helsinki Music Centre. Thesis: Clarinet Music from Russia and the Soviet Union 1917-1991: Discovering an Unexplored Side of the Clarinet Repertoire. Artistic project:"The concert series consisted of clarinet music from Russia and the Soviet Union 1917-1991, featuring the clarinet in various instrument combinations: solo, with piano, and chamber music with clarinet, piano and strings". Custos: DMus Anu Vehviläinen. Statement on the demonstration of artistic proficiency: DMus Mikko Raasakka. Statement of the thesis: Prof. Dr. Marina Frolova-Walker. Performers: Anne Elisabeth Piirainen, clarinet; Kirill Kozlovski, piano; Lea Tuuri, violin; Maria Puusaari, violin; Jussi Aalto, viola; Pinja Nuñez, cello.
\end{abstract}

When I travelled from my small West-German hometown to Moscow in 1990 in order to study the clarinet at the Tchaikovsky Conservatory, I could not have imagined that it would one day lead to my doctoral research topic. During my further professional life as performing clarinettist and pedagogue in various European countries, one main question, however, continued to occupy my mind: Why does the standard clarinet repertoire contain so few compositions from Russia and the former Soviet Union? In symphonic, vocal or piano music, for example, there are plenty of famous works from Russian and Soviet composers. When it comes to the clarinet, however, compositions from this field can be counted on one hand. This leads to the next question: Is this lacuna simply due to a dearth of clarinet music in this field, or is it out there somewhere but just hidden? Delving deeper into this matter, I ended up devoting my artistic doctoral research to this topic: "Clarinet Music from Russia and the Soviet Union 1917 to 1991: Discovering an unexplored Side of the Clarinet Repertoire".

This research consists of a series of five doctoral concerts, a thesis in form of a website and a database on Russian and Soviet clarinet music. Despite vast research activity in other fields of Russian and Soviet music studies, there remains too little information available concerning clarinet music from this field. Manifold studies are devoted to other aspects of clarinet music, but there is a clear research gap in this 
part of the repertoire. In my research, I explore the aesthetic qualities and creative potential of this repertoire from the view of a performing clarinettist. Especially important to me as a performer-researcher is prospecting the artistic significance of these compositions in a present-day context.

I was initially unable to foresee the dimensions of this project. Taking as a starting point the few commonly known clarinet works from this field, during my research I uncovered hundreds of works, more than I ever could have expected. Some of these compositions were neither recorded nor performed, while others remained unpublished. Several compositions have been entirely forgotten, waiting to be awoken from their Cinderella sleep in Russian archives and libraries. Most astonishing is not the sheer volume of materials so much as the fact that there are even compositions of extraordinary musical value that remain virtually unknown.

One such composition which would deserve a place in the common clarinet repertoire is the Clarinet Quintet by Aleksandr Lokshin. Dmitri Shostakovich called Lokshin a 'genius', but Lokshin's life took a tragic turn under Stalin's dictatorship, and his music remains undervalued even today. We will now perform the first movement, Andante sostenuto.

Music performance. Aleksandr Lokshin: Quintet for clarinet and strings, $1^{\text {st }}$ movement.

\section{The ARTISTIC PROJECT}

My five doctoral concerts formed the artistic core, experimental space and public platform for my research. Out of the multitude of clarinet works which I examined during my studies, I created five concert programs consisting entirely of clarinet music composed between the Russian Revolution of 1917 and the dissolution of the Soviet Union in 1991. These concerts aimed to give wide-ranging insights on this lesser-known aspect of the clarinet repertoire, both to the audience and to myself in a research context. I chose cross-sections of works from different styles and periods, looking for musical and clarinetistic connections among the performed works. One main objective was to explore various expressional facets of this specific music. I explained the clarinetistic particularities of each work and pointed out unknown repertoire gems that I felt deserved broader attention. Furthermore, each concert included at least one well-known composition as part of the "standard clarinet repertoire".

The clarinet was featured in various instrument combinations, from solo to chamber music settings. The latter expresses my strong personal affinity for playing chamber music, which emphasizes the process of interacting and communicating with co-musicians and the audience. Each concert was built upon a thematic con- 
cept. I grouped my research into seven subtopics, several of which I touched upon in each concert:

- Clarinet works with Jewish Themes

- "Undesired" or suppressed compositions under Stalin

- Clarinet compositions from the period of the "Thaw"

- Clarinet music from "Khrennikov's Seven” - a composers' circle around Denisov

- Changes in the clarinet repertoire during Perestroika

- Clarinet works from the Baltic Republics from the years under Soviet rule

- Works from selected Émigré composers

The title of my first doctoral concert, Abandoned Melodies, contains various connotations. First, socio-political circumstances, which had significant impact on the work of the composers. For example, Aleksandr Veprik, Joseph Dorfman and Aleksandr Lokshin were made to suffer personal and professional repression in the Soviet Union. Secondly, the general problem of neglect and lack of performance practice of this repertoire. Just a few works from this field, such as Edison Denisov's compositions, have found their way into the standard clarinet repertoire. The case of Mieczysław Weinberg, however, is a positive example of how interest among scholars and performers can rediscover a composer and revive worthy music within a relatively short time.

My second doctoral concert was dedicated to clarinet music from the Moscow and St Petersburg composers' schools. I was searching for different perspectives from which to interpret the topic Between Love and Hate. Besides questions of historic rivalry and artistic conflicts, I have given special attention to the musical connections among the chosen compositions. Some works we can look at from the perspective of personal relations, the struggle for independence and for artistic recognition, such as with Galina Ustvolskaya, Grigory Frid, or Grigory Krein. Boris Tishchenko and Elena Firsova disclose inner conflicts and sharp musical contrasts in their work. However, my main motivation in titling this concert Between Love and Hate was to explore the vast spectrum of characters and emotions in the performed compositions.

To me as a performer, the juxtaposition of some of the most popular clarinet works with seldom-heard ones is an appealing artistic challenge: approaching the repertoire from a given reference frame, or creating an entirely new path. In the third doctoral concert program, Facets of Expression, standard clarinet repertoire works by Sergey Prokofiev and Aram Khachaturian provided a framework for lesser-known compositions by Arthur Lourié, Maija Einfelde and Katia Tchemberdji. The connecting line within these compositions is the wealth of expressive possibilities of the clarinet, exploring the contrast between well-established performance practices on the one hand, and the fascinating process of internalizing previously 
unknown works on the other hand.

My fourth doctoral concert, Echoes of the Past, explored musical and cultural interconnections among the compositions by revealing influences of the past on the present from different angles. To me as a performer, one especially intriguing aspect in this concert program is the perception of a time frame - how a composition can "feel" as if it comes from an entirely different period than the one it was actually composed in. Mitya Stillman sets Jewish themes in a nostalgic light, Efrem Podgaits mixes "old and new", classical and popular music genres. Vladimir Tarnopolsky crosses established notions of classical music, literature and history with the use a radical avantgardist musical language. Grigory Krein reflects on his Jewish background through French fin-de-siècle musical ideals, whereas Edison Denisov alludes to one of the early masterpieces of our repertoire, the clarinet quintet by Mozart.

The last concert was entitled Beyond Borders. The idea of Borders can be interpreted here in diverse ways. This repertoire is bordered by distinct styles and time periods. Related to the concept of borders are also questions of nationality, citizenship and ethnic roots: these compositions originate from a state that no longer exists - the former Soviet Union. Yury Kasparov mirrors musical gestures of the second Viennese school, yet his work is composed within very different times and circumstances. Vyacheslav Artyomov's composition is situated on the breaking point between traditional and extended clarinet playing techniques in Russia. Samuil Senderey crosses the border between classical and folk music, whereas Vladimir Agopov reveals an enhanced expressivity within the rules of dodecaphonic composition techniques. Olga Rayeva transcends physical borders in her composition for clarinet and theremin, the only musical instrument which is played without touching it. When hearing Grigory Krein's music without knowing where and when it was composed, it could be difficult to guess that his work originated in the Soviet Union under Stalin.

Of all of these borders, there is one that lies in our, the performers', hands: all of these compositions are primarily situated outside the standard clarinet repertoire. The question arises in how far we actually create borders ourselves in our thinking, our choices and actions? How aware are we of limiting our repertoire by neglecting parts of it, and the far-reaching consequences of our selections? This concern closes the circle and leads back to the topic of the very first concert, Abandoned Melodies. It underlines the main motivation and purpose of my research - to shed light on an overlooked repertoire. Numerous works have even faced double neglect: repudiated during the composers' lifetimes only to be forgotten in our own. As one example of an abandoned work with Jewish Themes, we will now perform Chant Rigoureux by Aleksandr Veprik.

Music performance. Aleksandr Veprik: Chant Rigoureux op. 9 for clarinet and piano. 


\section{The THESIS AND METHODS}

The thesis of my artistic doctoral research has the same title as the concert series. It was a central concern for me to treat the thesis and my artistic practice as one inseparable entity, mirroring my work and identity as a performing musician-researcher. The thesis is published in the form of a website and consists of three parts. The first part is devoted to the series of doctoral concerts as I described earlier. The second part of the thesis is entitled "A Performer's Approach to Russian and Soviet Clarinet Music". In this part, I contextualize and discuss the repertoire within historical and musical frames from my view as a performing clarinettist. I deliberately chose the online format of a website for multiple reasons. First, because I wished to integrate video excerpts from my live performances in the written text. Instead of solely using printed score examples, through the use of video I aim to draw attention to the act and significance of performance and clarinet playing in the research context. Part three of the thesis is a database that I compiled which includes information on over five hundred Russian and Soviet compositions with the clarinet. The search function of the database can be carried out ideally in an online format. This database aims to close the information gap on this facet of the clarinet repertoire and can be a starting point for further research in this field. Finally, the website format enables easy and broad access of information to the interested reader, such as clarinettists, other musicians, or scholars.

For this study, I have applied multifaceted methods, skills and approaches. My point of view as a performing clarinettist has influenced my entire research process, from the acquisition of the information and material, in particular the scores, to the performance of the compositions, to the reflection and analysis that I convey through the performance. The research process can be divided into different stages, each of which requires specific methods and competencies. My first task was to obtain information on what could have possibly been composed for the clarinet during the period of the former Soviet Union. As there exists no comprehensive repertoire list or any specialized catalogue, I consulted numerous and diverse sources to find out which composers wrote for our instrument. Among these sources are composer biographies and work listings, repertoire bibliographies and musical encyclopaedias, music publishers, libraries, archive catalogues, discographies and general literature on Soviet music history. The next step was to locate the sheet music if at all possible. Especially important at this point were the libraries and archives in Moscow and St Petersburg which I consulted, and here I must declare that there still remains plenty of exciting material to be discovered in those archives!

Further, I have contextualized the compositions within the historical frame and musical style of the time period, pointing out general lines in the development of the clarinet repertoire from this field. I have also contextualized each composition individually, using my own personal reference frame of the common clarinet reper- 
toire, as well as of other musical genres such as symphonic works. The next phase deals with selecting and organizing the compositions into meaningful and musically coherent concert programs. Then, through the process of rehearsing and performing these works, I acquired specific information which became my personal, silent knowledge. I pay special attention to bodily and mental experiences while playing the clarinet. Also, I examine to what extent a work is composed idiomatically for the clarinet. Taken together, these various stages form my personal approach to this research, through my perspective as a performing clarinettist.

I would now like to perform music by another highly prolific composer, Yulian Krein. Yulian, son of the Jewish-Russian composer Grigory Krein, was a childprodigy and studied with Paul Dukas in Paris. Back in the Soviet Union, he had to fight for recognition, and his music remains undervalued even today. We will now perform the first movement, Andante, of Yulian Krein's Clarinet Sonata.

Music performance. Yulian Krein: Sonata for clarinet and piano, $1^{\text {st }}$ movement.

\section{Conclusions AND OUTLOOK}

Looking towards the future, there are many possibilities for how to continue expanding upon this topic. One central issue is the inadequate availability of scores of this repertoire. New sheet music editions need to be produced in order to increase interest among performers and to make new recordings and performances possible. The vicious circle of lack of information, resulting in little interest, leading to further neglect of the topic, needs to be broken. Several research projects can grow out of the enormous amount of material and works which still remain under-researched and unperformed. If I had to choose one direction to go in, I would call for a deeper examination of clarinet music from the Stalin era, especially the work of suppressed composers, and in particular those clarinet compositions with Jewish themes. The impact of research on such disregarded music goes beyond merely historical questions. When considering that minorities are suffering from repression more and more all over the world; radical and nationalist tendencies again are gaining steam; human rights, freedom of speech and artistic expression are increasingly under threat; the need for such research and its significance is indisputable.

As a last example of a composition that deserves broader attention, we will now perform the first movement of the Quartet by Grigory Krein, father of Yulian Krein. He was, like Aleksandr Veprik, a member of the so-called New Jewish school in music and suffered oppression under the dictatorship of Stalin. In 1927 the eminent musicologist Leonid Sabaneyev wrote in his book Modern Russian Composers the following about Grigory Krein: "And thus this great artist lives unrecognised by the world, not even properly observed by his musical intimates, keeping up his 
creative work in spite of all discouragement. Creative work of this kind is usually rewarded with fame after death, or with belated if firm recognition. One hopes that the time is not distant when it will become known on a scale which it justly merits". ${ }^{1}$

Who could have imagined that Sabaneyev's words could still be so relevant, almost one century later! My sincere hope is that my artistic doctoral research will initiate further interest in this neglected part of the clarinet repertoire and be a starting point for reviving music which deserves to be heard.

Music performance. Grigory Krein: Quartet for clarinet, violin, cello and piano, $1^{\text {st }}$ movement.

1 Leonid Sabaneyeff 1927. Modern Russian Composers. New York: International Publishers, s. 189. 